\author{
JOLANTA BLICHARZ \\ ORCID: 0000-0002-4581-8629 \\ Uniwersytet Wrocławski
}

\title{
OCHRONA PRAW DZIECKA NA TLE KONSTYTUCJI RP Z 1997 ROKU - RAMY NORMATYWNE
}

\begin{abstract}
Abstrakt: Ochrona praw dziecka zyskuje niezwykle mocną podstawę normatywną — tworzą ją nie tylko normy prawa międzynarodowego, ale i krajowego. Regulacje Konstytucji nadały ochronie praw dziecka nie tylko formalnie rangę konstytucyjną, ale także wprowadziły obowiązki organów władzy publicznej do przestrzegania tych norm konstytucyjnych, jak również norm prawa międzynarodowego odnoszących się do ochrony praw dziecka i rodziny. Można więc uznać, że współcześnie ochrona praw dziecka wywiera konkretny i widoczny wpływ na funkcjonowanie całości systemu prawa, którego głównym założeniem jest nakaz uwzględniania w procesie stanowienia i stosowania prawa ,dobra dziecka”.
\end{abstract}

Słowa kluczowe: prawa człowieka, dobro dziecka, ochrona praw, ochrona praw człowieka

\section{REGULACJE KONSTYTUCYJNE DOTYCZĄCE PRAW DZIECKA}

Ochrona praw dziecka dysponuje niezwykle mocną podstawą normatywną tworzą ją nie tylko normy prawa międzynarodowego, ale i krajowego. W prawie polskim zawarta jest ona w Konstytucji i szeregu aktów prawnych, zwłaszcza w ustawie o Rzeczniku Praw Dziecka ${ }^{1}$, która mówi, że Rzecznik działa na rzecz ochrony praw dziecka, w szczególności uwzględniając prawa do życia i ochrony zdrowia, prawa do wychowania w rodzinie, prawa do godziwych warunków socjalnych, prawa do nauki.

Nie można tracić z pola widzenia faktu, że Konstytucja jako najwyższej rangi dokument $\mathrm{w}$ hierarchii polskich podstaw normatywnych stoi na straży ochrony praw dziecka. Jest fundamentalnym aktem prawnym w Polsce zawierającym między innymi regulacje dotyczące praw dziecka. Nadto ochrona praw dziecka zawarta jest w szeregu aktów prawnych regulujących różne dziedziny życia, na przykład edukację, opiekę i zdrowie, a także w ustawach kodeksowych takich,

${ }^{1}$ Ustawa z dnia 6 stycznia 2000 roku o Rzeczniku Praw Dziecka, Dz.U. z 2020 r. poz. 141. 
jak: Kodeks Rodzinny i Opiekuńczy ${ }^{2}, K_{\text {Kodeks Cywilny }}^{3}$, Kodeks Postępowania Cywilnego ${ }^{4}$, Kodeks Pracy ${ }^{5}$ i Kodeks Karny ${ }^{6}$.

Na uwagę zasługują uregulowania konstytucyjne zawierające katalog podstawowych praw i wolności obywatelskich (art. 30 do 76), a także szczególne przepisy dotyczące bezpośrednio praw dziecka, a mianowicie: art. 18 (ochrona i opieka państwa nad rodziną, macierzyństwem i rodzicielstwem), art. 48 ust. 1 (prawo rodziców do wychowania dziecka zgodnie $\mathrm{z}$ własnym przekonaniem, z powinnością uwzględnienia stopnia dojrzałości dziecka, wolności jego sumienia i wyznania oraz przekonań), art. 53 ust. $3 \mathrm{w}$ związku z art. 48 ust. 1 (prawo rodziców do zapewnienia dzieciom wychowania oraz nauczania religijnego i moralnego zgodnie ze swoimi przekonaniami), art. 65 ust. 3 (zakaz stałego zatrudniania dzieci do lat 16), art. 68 ust. 3 (prawo m.in. dzieci do zapewnienia im przez władze publiczne szczególnej opieki zdrowotnej), art. 70 ust. 1 i 2 (prawo do nauki, obowiązkowa nauka do 18 roku życia, bezpłatność nauki w szkołach publicznych), art. 71 (pomoc władz publicznych dla rodzin wielodzietnych i niepełnych, dla matek przed i po urodzeniu dziecka), art. 72 (ochrona praw dziecka, obowiązek ochrony dziecka przed przemocą, okrucieństwem, wyzyskiem i demoralizacją; prawo do opieki i pomocy władz publicznych dla dziecka pozbawionego opieki rodzicielskiej; obowiązek wysłuchania i w miarę możliwości uwzględnienia zdania dziecka przez organy władzy publicznej oraz osoby odpowiedzialne za dziecko w toku ustalania praw dziecka; powołanie Rzecznika Praw Dziecka) ${ }^{7}$.

Wypada też wspomnieć, że w orzecznictwie TK odnoszącym się do pojęcia praw dziecka oraz w przepisach Konstytucji szczególne miejsce zajmują rozstrzygnięcia dotyczące definicji tego pojęcia. W wyroku z dnia 28 kwietnia 2003 roku, sygn. K 18/02, TK przyjął, że pojęcie praw dziecka w przepisach Konstytucji należy rozumieć jako „nakaz zapewnienia ochrony interesów małoletniego, który w praktyce sam może jej dochodzić w bardzo ograniczonym zakresie"8. W kolejnym orzeczeniu z dnia 11 października 2011 roku, K 16/1, TK zwrócił uwagę, że „rodzice winni mieć zatem prawo do reprezentowania dziecka względem osób trzecich, by móc efektywnie sprawować nad nim pieczę. Przysługuje im w tym względzie prawo podmiotowe o charakterze przyrodzonym i naturalnym, niepochodzące z nadania państwowego, choć wykonywane pod kontrolą państwową

${ }^{2}$ Ustawa z dnia 25 lutego 1964 roku — Kodeks rodzinny i opiekuńczy, Dz.U. z 2020 r. poz. 1359.

3 Ustawa z dnia 23 kwietnia 1964 roku - Kodeks cywilny, Dz.U. z 2021 r. poz. 1509.

${ }^{4}$ Ustawa z dnia 17 listopada 1964 roku — Kodeks postępowania cywilnego, Dz.U. z 2021 r. poz. 1805.

5 Ustawa z dnia 26 czerwca 1974 roku - Kodeks pracy, Dz.U. z 2020 r. poz. 1320.

${ }^{6}$ Ustawa z dnia 6 czerwca 1997 roku — Kodeks karny, Dz.U. z 2020 r. poz. 1444, 1517.

7 Zob. też S.L. Stadniczenko, Ochrona praw dziecka wynikajaca z art. 19 Konwencji o Prawach Dziecka oraz art. 72 Konstytucji RP, „Zeszyty Naukowe Państwowej Wyższej Szkoły Zawodowej im. Witelona w Legnicy” 2017, nr 22, s. 10.

8 OTK ZU nr 4/A, poz. 32. 
i społeczną"9. Na straży rodzicielstwa stoi także Konstytucja RP, która gwarantuje ochronę macierzyństwa i rodzicielstwa (art. 18).

Należy przy tym zaznaczyć, że dziecko jest odrębnym podmiotem konstytucyjnych praw i wolności. O tej odrębności przesądza zarówno art. 72 Konstytucji, stanowiący ściśle o ochronie praw dziecka, jak i regulacje cząstkowe w zakresie poszczególnych konstytucyjnych praw i wolności, a mianowicie: o swobodzie w zakresie wolności sumienia i wyznania i w procesie wychowania dziecka (art. 48 ust. $1 \mathrm{i}$ art. 53 ust. 3), prawa w zakresie opieki zdrowotnej (art. 68 ust. 3) i ochrony przed wyzyskiem ekonomicznym wyrażającej się w zakazie stałego zatrudniania dzieci poniżej 16 lat (art. 65 ust. 3), prawa do nauki (art. 70 ust. 1 i 3) oraz pomocy socjalnej (art. 71) ${ }^{10}$.

Dziecku, podobnie jak osobie dorosłej, przysługuje pełnia praw człowieka ${ }^{11}$, których źródłem jest godność będąca rudymentarnym elementem całego systemu konstytucyjnych praw i wolności. Jednocześnie umieszczenie przepisów o ochronie praw dziecka (art. 72) pośród praw socjalnych należy interpretować jako dodatkowe, obok praw osobistych i politycznych, prawo dziecka do ochrony i opieki ze strony państwa ${ }^{12} \mathrm{z}$ uwzględnieniem najlepiej rozumianego interesu i dobra dziecka. Z tego względu państwo przy realizacji zapewnienia dziecku ochrony i opieki — w takim stopniu, w jakim jest to niezbędne dla jego dobra — musi brać pod uwagę prawa i obowiązki rodziców, opiekunów prawnych lub innych osób prawnie odpowiedzialnych za dzieci oraz podejmować wszelkie właściwe kroki ustawodawcze oraz administracyjne ${ }^{13}$.

Jak podkreślił TK w sprawie K 18/02, ochrona praw dziecka należy do „wyjątkowo doniosłych" wartości konstytucyjnych. Celem ochrony jest dobro dziecka, które „stanowi swoistą konstytucyjną klauzulę generalną, której rekonstrukcja powinna się odbywać poprzez odwołanie do aksjologii konstytucyjnej i ogólnych założeń systemowych. [...] Nakaz ochrony dobra dziecka stanowi podstawową, nadrzędną zasadę polskiego systemu prawa rodzinnego, której podporządkowane są wszelkie regulacje w sferze stosunków pomiędzy rodzicami i dziećmi"14.

Podkreślenia wymaga fakt, że na gruncie art. 48 ust.1 Konstytucji RP dzieckiem jest osoba niepełnoletnia, ponieważ taka osoba ze względu na swoją nie-

9 Dz.U. z 2003 r. Nr 83, poz. 772. Zob. też wyrok TK z dnia 17 kwietnia 2007 roku, SK 20/05, OTK-A 2007/4/38.

10 Zob. E.H. Morawska, Ochrona praw dziecka w świetle art. 72 Konstytucji RP. Uwagi na tle orzecznictwa Trybunatu Konstytucyjnego, „Kwartalnik Prawa Publicznego” 2007, nr 4, s. 126.

11 Szerzej G. Mikołajczyk-Lerman, Konwencja o Prawach Dziecka a realizacja praw dziecka z niepetnosprawnościa w relacjach rówieśniczych, „Przegląd Socjologii Jakościowej” 13, 2017, nr 4, s. $31 \mathrm{n}$.

12 E.H. Morawska, op. cit., s. 127.

13 S.L. Stadniczenko, Prawo dziecka do wychowania..., s. 46.

14 Wyrok TK z dnia 28 kwietnia 2003 roku, K 18/02, OTK-A 2003/4/32. 
dojrzałość pozostaje pod opieką rodziców ${ }^{15}$. Z kolei w myśl art. 1 Konwencji o Prawach Dziecka ${ }^{16}$ pojęcie ,dziecko oznacza każdą istotę ludzką w wieku poniżej osiemnastu lat, chyba że zgodnie z prawem odnoszącym się do dziecka uzyska ono wcześniej pełnoletniość". Należy również wziąć pod uwagę i ten fakt, że w preambule Konwencji o Prawach Dziecka ustawodawca międzynarodowy podkreśla, że „dziecko, z uwagi na swoją niedojrzałość fizyczną oraz umysłową, wymaga szczególnej opieki i troski, w tym właściwej ochrony prawnej, zarówno przed, jak i po urodzeniu". Na tej podstawie można przyjąć, że brak określenia dolnej granicy wieku dziecka w postanowieniach Konwencji należy interpretować jako objęcie ochroną od początku życia, to jest od momentu poczęcia ${ }^{17}$. W tym miejscu warto też podnieść, że obowiązująca ustawa o Rzeczniku Praw Dziecka rozciąga ochronę także na dzieci poczęte (nienarodzone) ${ }^{18}$.

\section{DOBRO DZIECKA W RAMACH ŻYCIA RODZINNEGO JAKO NIEODŁĄCZNY ELEMENT REGULACJI KONSTYTUCYJNEJ}

Szczególnie istotne znaczenie w kształtowaniu ochrony praw dziecka ma zasada dobra dziecka. W literaturze przedmiotu wskazuje się, że „pojęcie »dobra dziecka« ma charakter nieostry i ocenny, podlega indywidualnemu badaniu w konkretnych okolicznościach każdego przypadku"19. Zdaniem Z. Radwańskiego „pewna niedookreśloność tego pojęcia ma duże zalety, pozwalające uzupełnić jego treść o nowe osiągnięcia nauki - przede wszystkim pedagogiki i psychologii — oraz o nowe doświadczenia społeczne. [...] pozwala w konkretnym przypadku znaleźć najbardziej optymalne rozstrzygnięcie uwzględniające zarówno indywidualne cechy dziecka, jego konkretną sytuację, jak i pozostające do dyspozycji możliwości faktyczne" 20 .

Stwierdzenia te są nadal aktualne zarówno jeżeli chodzi o stan badań nad dobrem dziecka, jak i wzrastającą ochronę prawną dziecka, która powiększa jeszcze potrzebę badań.

Nauka prawa nie zaprezentowała dotąd ogólnej prawnej teorii dobra dziecka. Dotyczy to braku kompleksowych, całościowych koncepcji, bowiem zagad-

15 Zob. B. Banaszak, Konstytucja Rzeczypospolitej Polskiej. Komentarz, Warszawa 2009, s. $249-250$.

${ }^{16}$ Konwencja uchwalona przez Zgromadzenie Ogólne Narodów Zjednoczonych 20 listopada 1989 roku, ratyfikowana przez Polskę 30 kwietnia 1991 roku.

17 P. Zamelski, Prawo do życia i ochrony zdrowia, [w:] Konwencja o Prawach Dziecka. Wybór zagadnień (artykuły i komentarze), red. S.L. Stadniczenko, Warszawa 2015, s. 71.

18 W myśl art. 2 ust. 1 za dziecko uznaje się każdą istotę ludzką od poczęcia do pełnoletności.

19 A. Partyk, Dobro dziecka jako wartość nadrzędna przy orzekaniu o władzy rodzicielskiej, Warszawa 2020.

${ }^{20}$ Z. Radwański, Pojęcie i funkcja ,,dobra dziecka” w polskim prawie rodzinnym i opiekuńczym, „Studia Cywilistyczne” 1981, nr 31, s. 9 i 19. 
nienia szczegółowe (na przykład odnoszące się do zagadnień prawa rodzinnego) oraz fragmenty aspektów osoby dziecka stanowią przedmiot licznych opracowań. W sumie więc literatura jest obszerna. Stosunkowo duże zainteresowanie jest uzasadnione tym, że dobro dziecka jest nieodłącznym elementem regulacji konstytucyjnej gwarantującej w trybie art. 18 ochronę i opiekę Rzeczypospolitej małżeństwu, rodzinie, macierzyństwu i rodzicielstwu. Dobro dziecka jest również tą wartością, która determinuje kształt innych rozwiązań instytucjonalnych, w tym przede wszystkim na gruncie Kodeksu rodzinnego i opiekuńczego ${ }^{21}$, oraz stanowi główną treść Konwencji o Prawach Dziecka, w której wskazano, że „we wszystkich działaniach dotyczących dzieci, podejmowanych przez publiczne lub prywatne instytucje opieki społecznej, sądy, władze administracyjne lub ciała ustawodawcze, sprawą nadrzędną będzie najlepsze zabezpieczenie interesów dziecka" (art. 3 ust. 1).

Zwrócić należy jeszcze uwagę, że w orzecznictwie Sądu Najwyższego prezentowane jest stanowisko, zgodnie z którym „nadrzędny interes dziecka” w Konwencji ma takie samo znaczenie jak , dobro dziecka traktowane jako wartość nadrzędna"22. Jednocześnie zdaniem SN na uwagę zasługują zwłaszcza te sformułowania Konwencji, które wskazują, że dziecko dla pełnego i harmonijnego rozwoju powinno wychowywać się w środowisku rodzinnym ${ }^{23}$. Należy to tłumaczyć przede wszystkim tym, że rodzina jako podstawowa komórka społeczeństwa, aby mogła w pełnym zakresie wypełniać swoje obowiązki w społeczeństwie, powinna być otoczona niezbędną ochroną oraz wsparciem.

$\mathrm{Na}$ teoretyczny kształt problematyki dobra dziecka składa się cały szereg zagadnień cząstkowych, każde o dużym ładunku teoretycznym. Można zatem przyjąć umownie, że zasady „dobro dziecka” i „,dobro rodziny” stanowią fundamentalną wartość prawną. Idąc dalej, można powiedzieć, że „dobro dziecka” i „dobro rodziny” nie są odmiennymi wartościami, lecz dwoma sposobami odwoływania się do tej samej wartości. Innymi słowy dobro dziecka — będąc pewnym nienaruszalnym minimum, które każdy akt prawny powinien zapewnić w ten sposób, aby interes małoletniego związany był z zapewnieniem odpowiednich warunków wychowania i rozwoju — nie może doznać uszczerbku, niezależnie od sytuacji w jakiej dziecko się znajdzie. Jednocześnie „,dobro dziecka” należy ujmować w szerszym aspekcie „,dobra rodziny” ${ }^{24}$, które jest w polskim systemie prawnym przedmiotem zasady konstytucyjnej (art. 18 i art. 71 Konstytucji RP),

21 Zob. wyrok TK z 28 kwietnia 2003 roku, K 18/02, OTK-A 2003/4/32.

22 Uchwała SN z dnia 12 czerwca 1992 roku, sygn. akt: III CZP 48/92, OSCN, 1992, nr 10, poz. 179. Warto podkreślić, że z art. 72 wynika ogólne uznanie dobra dziecka za samoistną wartość konstytucyjną uzupełniającą wartość szerszą, jaką jest dobro rodziny (B. Banaszak, M. Jabłoński, Uwagi do artykułu 72, [w:] Konstytucje Rzeczypospolitej oraz komentarz do Konstytucji RP z 1997 roku, red. J. Boć, Wrocław 1999, s. 32.

23 Ibidem.

24 Zob. A. Partyk, op. cit. 
albowiem to właśnie w rodzinie dziecko znajduje najlepsze środowisko do prawidłowego rozwoju 25 .

Dobro dziecka jest również tą wartością, która determinuje kształt innych rozwiązań instytucjonalnych, w tym przede wszystkim na gruncie Kodeksu rodzinnego i opiekuńczego. Jest ono również eksponowane jako wartość szczególna w Konwencji o Prawach Dziecka, gdzie w art. 3 ust. 1 wskazano, że „we wszystkich działaniach dotyczących dzieci, podejmowanych przez publiczne lub prywatne instytucje opieki społecznej, sądy, władze administracyjne lub ciała ustawodawcze, sprawą nadrzędną będzie najlepsze zabezpieczenie interesów dziecka" 26 .

Także na gruncie doktryny podnoszone jest stanowisko, zgodnie z którym dobro dziecka jako pojęcie stanowi jądro wszystkich przepisów o prawach dziecka, będąc przysłowiowym „duchem ustawy”. Jest instrumentem wykładni zarówno norm zawartych w Konwencji o Prawach Dziecka, jak i prawa krajowego państw, które ją podpisały. Jest również dyrektywą w przypadku tworzenia prawa i jego stosowania, kryterium oceny przy podejmowaniu decyzji w sprawach dziecka oraz rozstrzyganiu kolizji interesów dziecka i innych osób, zwłaszcza rodziców ${ }^{27}$. Podkreśla się też, że dążenie do ochrony dobra dziecka było również „myślą przewodnią, na której oparte zostały przepisy Kodeksu rodzinnego i opiekuńczego o uznaniu dziecka"28.

Przyjmując założenie, że zasada dobra dziecka najpełniej realizowana jest poprzez zapewnienie wychowania dziecka w rodzinie, należy wskazać, że to właśnie rodzice są jego pierwszymi edukatorami, którzy w poczuciu odpowiedzialności mają stworzyć mu odpowiednie warunki rozwoju fizycznego i duchowego ${ }^{29}$. Jednocześnie proces wychowania dziecka wspierany jest przez prawodawcę przy pomocy licznych rozwiązań normatywnych, które mają pomóc rodzicom i opiekunom prawnym troszczyć się o jego prawidłowy rozwój fizyczny i duchowy ${ }^{30}$ przez udzielanie rodzinie pomocy w ramach prowadzonej polityki prorodzinnej, prawnej, społecznej oraz gospodarczo-ekonomicznej, umożliwiając tym samym urzeczywistnienie prawa dziecka do życia i rozwoju w rodzinie ${ }^{31}$.

25 Por. A. Sylwestrzak, O klauzuli generalnej dobra rodziny, „Studia Prawnoustrojowe” 2019, nr 45, s. 313.

26 Wyrok TK z dnia 17 kwietnia 2007 roku, SK 20/05, OTK-A 2007/4/38.

27 W. Stojanowska, Władza rodzicielska pozamalżeńskiego i rozwiedzionego ojca. Studium socjologiczno-prawne, Warszawa 2000, s. 32.

28 System prawa rodzinnego, red. J.S. Piątowski, Warszawa 1985, cz. 1, s. 692.

29 Por. H. Babiuch, Konstytucyjne prawa rodziców w zakresie wychowania dziecka, https:// repozytorium.uni.wroc.pl/Content/52921/PDF/10_Helena_Babiuch.pdf, s. 183 (dostęp: 26.01.2021).

${ }_{30}$ Zob. M. Bielecki, Ochrona rodziny i życia rodzinnego w kontekście wychowywania zgodnie z przekonaniami rodziców, Warszawa 2020, s. 9; L. Zacharko, B. Wartenberg-Kempka, Dobro dziecka jako wartość najwyższa w prawie administracyjnym, [w:] Aksjologia prawa administracyjnego, t. 1, red. J. Zimmermann, Warszawa 2017, s. 281 n.

31 Por. S.L. Stadniczenko, Prawa dziecka częścia składowa systemu praw człowieka i obywatela, [w:] Konwencja o Prawach Dziecka. Wybór zagadnień (artykuly i komentarze), red. S.L. Stadniczenko, Warszawa 2015, s. $46 \mathrm{n}$. 
Analizując sposób regulowania władzy rodzicielskiej przyjmuje się, że stanowi ona kompleks wzajemnie ze sobą powiązanych praw i obowiązków rodziców w stosunku do osoby dziecka ${ }^{32}$. Co prawda w powszechnym odczuciu zasada dobra dziecka najpełniej realizowana jest poprzez zapewnienie wychowania dziecka w rodzinie naturalnej ${ }^{33}$, w której relacje między rodzicami i dziećmi są oparte na więzi biologicznej, jednak z drugiej strony nie można negować faktu, że w niektórych sytuacjach dobro dziecka może wymagać ochrony stosunków rodzinnych opartych na innego typu więzi niż biologiczna ${ }^{34}$ (na przykład przysposobienie, rodzina zastępcza, ustabilizowane relacje rodzinne).

Trzeba też zaznaczyć, że analiza pojęcia rodziny może być przeprowadzana w różnych jej aspektach, na przykład może dotyczyć jej socjologicznego ujęcia jako „najważniejszej” grupy społecznej stanowiącej „,podstawową komórkę społeczną, a więc fundamentalny, konstytutywny element każdego społeczeństwa"35. Można następnie przedstawić określenie rodziny na gruncie psychologii jako „grupę podstawową” dla jednostki, to znaczy „taką, której członkowie pozostają ze sobą w bliskim kontakcie i wzajemnie ze sobą współdziałają" ${ }^{36}$. Wreszcie można jeszcze mówić o rodzinie we współczesnych naukach pedagogicznych, gdzie „rodzina jest przede wszystkim środowiskiem wychowawczym, które tworzą zarówno oddziaływania zamierzone, jak też samorzutne, o charakterze pozytywnym, prowadzące do rozwoju dziecka"37.

Co prawda zadaniem nauki jest między innymi teoretyczne opracowywanie ogólnych zasad funkcjonowania rodziny, jednak bez odwołania się do podstaw prawnych nie można odtworzyć istoty rodziny, tak jak bez odwołania się do teorii nie można właściwie tworzyć i stosować przepisów prawnych. Przedmiot regulacji prawnej rzutuje niewątpliwie na samą regulację i jej formy. W konsekwencji chodzi o ustalenie sposobu regulowania instytucji rodziny i jej ochrony w świetle przepisów prawa krajowego i międzynarodowego ${ }^{38}$.

32 Por. H. Babiuch, Konstytucyjne prawa..., op. cit., s. 181.

33 Szerzej: ibidem, s. 183.

${ }^{34}$ Zob. wyrok TK z dnia 28 kwietnia 2003 roku, K 18/2002, OTK ZU 2003/4A poz. 32.

35 Rodzina, [hasło w:] Encyklopedia socjologii, t. 3, red. Z. Bokszański, Warszawa 2000, s. 312.

36 G. Makietlo-Jarża, Rodzina, [hasło w:] Encyklopedia psychologii, red. W. Szewczuk, Warszawa 1998, s. 734.

37 B. Krzesińska-Żach, Pedagogika rodziny. Przewodnik do ćwiczeń, Białystok 2007, s. 14.

38 Należy też podkreślić duży wkład Powszechnej Deklaracji Praw Człowieka w określeniu rodziny jako naturalnej i podstawowej komórki społeczeństwa uprawnionej do ochrony ze strony społeczeństwa i państwa (art. 16). Dodajmy, że PDPC jest pierwszym w dziejach całościowym sformułowaniem ludzkich praw. Również w art. 10 Paktu Praw Gospodarczych, Społecznych i Kulturalnych stwierdzono, że rodzina jest naturalną i podstawową komórką społeczną, a państwo powinno jej udzielać jak najszerszej ochrony i opieki. Jednocześnie wskazano, że ochrona i pomoc należą się rodzinie zwłaszcza w związku z odpowiedzialnością za opiekę i wychowanie dzieci (zob. M. Jabłoński, S. Jarosz-Żukowska, Prawa człowieka i systemy ich ochrony, Wrocław 2010, s. 173). 
Choć krajowe ustawodawstwo nie wprowadziło legalnej definicji rodziny ${ }^{39}$, to jednak na gruncie ustawy zasadniczej oraz regulacji cywilistycznych przyjmuje się, że rodzina stanowi „wspólnotę sformalizowaną, której podstawę może stanowić małżeństwo lub rodzicielstwo" 40 . Jednocześnie, analizując postanowienia Konstytucji, wypada zaznaczyć, że status tej podstawowej komórki społecznej wyznaczony jest przez szereg przepisów ustawy zasadniczej. I tak w końcowym fragmencie „Wstępu” do Konstytucji mówi się o „zasadzie pomocniczości umacniającej uprawnienia obywateli i ich wspólnot”. Można powiedzieć, że regulacja ta wyznacza także rolę rodziny w społeczeństwie ${ }^{41}$.

Dla ustalenia pojęcia rodziny na gruncie Konstytucji należałoby przyjąć, że ustrojodawca ustanawia zasadę ochrony małżeństwa rozumianego jako związek kobiety i mężczyzny. Ze względów teoretycznych, opierając się nadto na orzecznictwie TK, nie byłoby uzasadnione pominięcie również znaczenia rodziny w jej „pełnym”, jak i „,niepełnym” wymiarze. I tak rodzina ,pełna”, w tym „,wielodzietna”, składa się z „dwojga osób dorosłych pozostających we wspólnocie domowej i związanych więzami uczuciowymi oraz wychowywanego przez nie wspólnego dziecka (dzieci)”. Rodzinę „niepełną” tworzy natomiast jeden dorosły i wychowywane przez niego dziecko (dzieci) ${ }^{42}$.

Należy również wziąć pod uwagę także inne przepisy Konstytucji odwołujące się do rodziny, wskazujące przy tym obowiązki państwa wobec niej, a mianowicie: art. 18 deklarujący przyznanie ochrony i opieki małżeństwu, rodzinie, macierzyństwu i rodzicielstwu czy art. 33 ust. 1 ustanawiający zasadę równości praw kobiety i mężczyzny w życiu rodzinnym, a także art. 47 stanowiący o ochronie prawnej życia rodzinnego, jak również art. 48 ust. 2 dotyczący ochrony praw rodzicielskich. Ponadto w art. 48 ust. 1 zd. 1 i art. 53 ust. 3 wskazano prawo rodziców do wychowania dzieci zgodnie $\mathrm{z}$ własnymi przekonaniami, w tym do zapewnienia dzieciom wychowania i nauczania moralnego i religijnego. Natomiast w art. 71 zagwarantowano ochronę dobra rodziny i prawo rodziny oraz matki do pomocy ze strony władz publicznych. $Z$ kolei w art. 48 ust. 1 zd. 2 i art. 65 ust. 3, art. 68 ust. 3 oraz art. 72 ustanowiono ochronę praw dziecka, natomiast w art. $64 \mathrm{i}$ art. 21 ustanowiono gwarancję prawa dziedziczenia. Poza tym w art. 23 podkreślono rolę rodzinnego gospodarstwa rolnego.

39 Zob. A. Ziółkowska, A. Gronkiwicz, Rodzina w prawie administracyjnym - prolegomena, [w:] Rodzina w prawie administracyjnym, red. A. Ziółkowska, A. Gronkiewicz, Katowice 2015, s. 11.

40 A. Sylwestrzak, op. cit., s. 313-314.

41 Por. L. Garlicki, Uwaga 3 do art. 18, [w:] Konstytucja Rzeczypospolitej Polskiej. Komentarz, red. L. Garlicki, Warszawa 2003, s. 1-2.

42 Zob. na przykład L. Garlicki, Uwaga 4 do art. 71, [w:] ibidem, s. 2; M. Dobrowolski, Status prawny rodziny w świetle nowej Konstytucji Rzeczypospolitej Polskiej, „Przegląd Sejmowy” 1999, nr 4, s. 24; oraz wyrok TK z dnia 12 kwietnia 2011 roku, SK 62/8, OTK-A 2011/3/22. 


\section{INSTYTUCJA RZECZNIKA PRAW DZIECKA JAKO STRAŻNIKA PRAW DZIECKA}

Artykuł 72 ust. 4 Konstytucji RP odsyła do ustawy o Rzeczniku Praw Dziecka, zgodnie z którą Rzecznik przy wykonywaniu swoich uprawnień kieruje się przede wszystkim szeroko pojętym dobrem dziecka oraz bierze pod uwagę, że naturalnym środowiskiem jego rozwoju jest rodzina ${ }^{43}$. Jednocześnie najbardziej chronionymi dobrami dziecka są prawa: do życia i ochrony zdrowia; do wychowania w rodzinie; do godziwych warunków socjalnych; do nauki; do ochrony przed przemocą, okrucieństwem, wyzyskiem, demoralizacją, zaniedbaniem oraz innym złym traktowaniem (art. 3 ust. 2 i 3). Dodatkowo art. 3 ust. 4 ustawy podkreśla, że Rzecznik szczególną troską i pomocą otacza dzieci niepełnosprawne. Rozwinięcie powyższych postanowień stanowi art. 3 ust. 1 ustawy wskazujący na cele działań podejmowanych przez RPD, to jest na zapewnienie dziecku pełnego i harmonijnego rozwoju z poszanowaniem jego godności i podmiotowości.

Zarówno w doktrynie, jak i orzecznictwie sądowym przyjmuje się, że prawo do życia i ochrony zdrowia dziecka są ze sobą nierozerwalnie związane ${ }^{44}$. Uzasadnia się to między innymi tym, że przez życie należy rozumieć trwanie istoty ludzkiej ${ }^{45}$, z kolei samo prawo do ochrony życia jest nastawione na ochronę „biologicznej egzystencji człowieka"46. Podkreśla się też, że prawo do życia jest związane z godnością człowieka, zaś prawo do ochrony zdrowia to przede wszystkim prawo do zachowania życia i jego obrony, gdy jest zagrożone ${ }^{47}$. Warto przy tym zaznaczyć, że Konstytucja nie przewiduje zróżnicowania wartości ludzkiego życia ani nie dopuszcza ograniczenia tego prawa nawet w stanie nadzwyczajnym (art. 233, ust. 1) ${ }^{48}$. Nadto art. 32 Konstytucji gwarantuje prawną ochronę życia

43 Analizując treść art. 1 ust. 2 ustawy, w myśl którego Rzecznik Praw Dziecka „stoi na straży praw dziecka", należy przyjąć, że w sferze jego zainteresowania znajdują się wszelkie naruszenia praw i wolności dzieci, nie tylko w rodzinie, ale także w społeczeństwie i państwie (zob. Ł. Żukowski, Rola Rzecznika Praw Dziecka w ochronie praw dzieci, [w:] Realizacja i ochrona konstytucyjnych wolności i praw jednostki w polskim porządku prawnym, red. M. Jabłoński, Wrocław 2014, s. 877-878.

44 M. Zdyb, Ochrona praw dzieci w prawie polskim i międzynarodowym w kontekście ochrony ich zdrowia, „Studia Prawnicze KUL” 2018, nr 4, s. 153. Zob. też wyrok TK z dnia 7 stycznia 2004 roku, sygn. K 14/03, OTK-A 2004, nr 1, poz. 1; orzeczenie TK z dnia 8 maja 1997 roku, sygn. K 26/96, OTK 1997, nr 2, poz. 19; M. Mikos, M. Urbaniak, Prawo do bezpiecznej ochrony zdrowia $w$ świetle Konstytucji RP oraz rekomendacji Rady Europy i Rady Unii Europejskiej, „Medyczna Wokanda" 2016, nr 8, s. 162.

45 L. Garlicki, Komentarz do art. 2 Europejskiej Konwencji o Ochronie Praw Człowieka i Podstawowych Wolności, [w:] Europejska Konwencja o Ochronie Praw Człowieka i Podstawowych Wolności, t. 1. Komentarz do artykułów 1-18, red. L. Garlicki, Warszawa 2010, s. 67.

46 Konstytucje Rzeczypospolitej oraz komentarz do konstytucji RP z 1997 roku, red. J. Boć, Wrocław 1998, s. 78.

47 Zob. wyrok TK z dnia 7 stycznia 2004 roku, sygn. akt K 14/03, Dz.U. z 2004 r. Nr 5, poz. 37.

48 Ibidem. 
każdemu człowiekowi, zapewniając poszanowanie zasady równości. Zwrócić należy jeszcze uwagę, że art. 38 ustawy zasadniczej, zapewniający każdemu człowiekowi prawną ochronę życia, wskazuje jednocześnie, że ochrona ta zapewniana jest każdemu człowiekowi bez wyjątku, niezależnie na przykład od jego pozycji społecznej czy wieku ${ }^{49}$. Należy też się zgodzić ze stanowiskiem TK, że „demokratyczne państwo prawa jako naczelną wartość stawia człowieka i dobra dla niego najcenniejsze. Dobrem takim jest życie, które w demokratycznym państwie prawa musi pozostawać pod ochroną konstytucyjną w każdym stadium jego rozwoju" ${ }^{\text {50 }}$. Zdaniem TK chronione dobro prawne, jakim jest życie ludzkie, dotyczy też fazy prenatalnej ${ }^{51}$. Dla uzasadnienia swego stanowiska Trybunał przyjął między innymi treść preambuły Konwencji Praw Dziecka, która deklaruje w akapicie dziesiątym, nawiązując do Deklaracji Praw Dziecka, że to ostatnie z uwagi na swoją niedojrzałość fizyczną oraz umysłową wymaga szczególnej opieki i troski, a zwłaszcza właściwej ochrony prawnej, zarówno przed, jak i po urodzeniu. Według sądu konstytucyjnego „ujęcie tej reguły w preambule Konwencji musi prowadzić do wniosku, że zawarte w Konwencji gwarancje odnoszą się również do prenatalnej fazy ludzkiego życia"52. Jednocześnie w uzasadnieniu przywołanego orzeczenia TK stwierdził (analizując ówczesny art. 79 ust. 1 przepisów konstytucyjnych, wskazujący na obowiązek ochrony macierzyństwa i rodziny), że ochrona macierzyństwa nie może oznaczać wyłącznie ochrony interesów kobiety ciężarnej i matki, albowiem całość relacji na mocy art. 79 ust. 1 przepisów konstytucyjnych wskazuje na określoną relację pomiędzy kobietą a dzieckiem, w tym dzieckiem dopiero poczętym ${ }^{53}$. Powyższe ustalenia TK należałoby uznać za w pełni aktualne na gruncie obowiązującej Konstytucji RP z 1997 roku, w perspektywie art. 18 i art. 71 przyjmujących ochronę rodziny, macierzyństwa i rodzicielstwa. Podkreślenia wymaga również zawarty w Konstytucji obowiązek zapewnienia szczególnej pomocy dla rodzin znajdujących się w trudnej sytuacji materialnej i społecznej, zwłaszcza rodzin wielodzietnych i niepełnych (art. 71 ust. 1) czy matkom przed i po urodzeniu dziecka (art. 71 ust. 2).

Należy jeszcze wziąć pod uwagę treść art. 68 ust. 1 Konstytucji, z którego wynika, że każdy ma prawo do ochrony zdrowia. Jak słusznie stwierdził TK, słowo „każdy” oznacza, że „Konstytucja wyklucza jakiekolwiek wyłączenia podmiotowe z zakresu jej działania" 54 . Z tych względów należałoby, zdaniem Mariana Zdyba, „bezwarunkowo przyjąć, że prawo takie posiadają także dzieci”55. Jednocześnie w trybie art. 68 ust. 3 Konstytucji wśród wskazanych czterech grup społecznych,

\footnotetext{
49 Zob. Konstytucje Rzeczypospolitej..., s. 78.

50 Orzeczenie TK z dnia 28 maja 1997 roku, sygn. K 26/96, OTK 1997/2/19.

51 Ibidem.

52 Ibidem.

53 Ibidem.

54 Wyrok TK z dnia 7 stycznia 2004 roku, sygn. K 14/03, OTK-A 2004, nr 1, poz. 1.

55 M. Zdyb, Ochrona praw dzieci..., op. cit., s. 155.
} 
które ustrojodawca zdecydował się uprzywilejować w zakresie zapewnienia im przez władze publiczne szczególnej opieki zdrowotnej, są między innymi dzieci, kobiety ciężarne, osoby niepełnosprawne i w podeszłym wieku ${ }^{56}$.

W tym miejscu warto odwołać się do poglądu doktryny, że prawo do ochrony zdrowia jest prawem podstawowym wynikającym z przyrodzonej i niezbywalnej godności człowieka, którego przestrzeganie władza państwowa jest zobowiązana ochraniać $^{57}$. Z kolei ustalając treść prawa podmiotowego do ochrony zdrowia, o którym mowa w art. 68 ust. 1 Konstytucji, należy odnotować te wypowiedzi TK, w których przyjęto, że „treścią prawa do ochrony zdrowia nie jest abstrakcyjnie określony stan zdrowia poszczególnych jednostek, ale możliwość korzystania z systemu ochrony zdrowia funkcjonalnie ukierunkowanego na zwalczanie i zapobieganie chorobom, urazom i niepełnosprawności" 58 .

Zatem dużą doniosłość z punktu widzenia ochrony zdrowia dzieci (tak jak i dorosłych) ma nie tylko proces leczenia chorób i innych zaburzeń, ale również działania profilaktyczne oraz eliminowanie potencjalnych źródeł zachorowań ${ }^{59}$. W konsekwencji ochrona zdrowia dzieci (jak i dorosłych) musi być podporządkowana ochronie życia, które ma charakter nadrzędny ${ }^{60}$.

Problematyka prawa dziecka do ochrony zdrowia znalazła też odzwierciedlenie w Konwencji o Prawach Dziecka, która uznaje prawo każdego dziecka „do najwyższego poziomu zdrowia i udogodnień w zakresie leczenia chorób oraz rehabilitacji zdrowotnej”, zakazując przy tym jakichkolwiek form dyskryminacji w tym zakresie (art. 24 ust. 1). Dodać należy ponadto, że prawo dziecka do ochrony zdrowia implikuje również ochronę jego praw jako pacjenta. $Z$ tego względu należy zgodzić się ze stanowiskiem, że „dziecko jako pacjent, podobnie jak osoba dorosła, posiada pełne prawo do poszanowania godności, intymności, uzyskania świadczeń zdrowotnych odpowiadających aktualnemu stanowi wiedzy medycznej, doświadczenia śmierci w sposób jak najmniej uciążliwy i bezbolesny itp." ${ }^{\prime 61}$.

W obszarze działalności Rzecznika Praw Dziecka na rzecz ochrony praw dziecka znajduje się niewątpliwie prawo dziecka do godziwych warunków so-

56 Szerzej zob. M. Dercz, Konstytucyjne prawo dziecka do szczególnej opieki zdrowotnej, Warszawa 2016.

57 Zob. A. Zoll, Problemy stużby zdrowia w świetle doświadczeń RPO, „Prawo i Medycyna” 2000, nr 8. Również zdaniem M. Piechoty „w zakresie, w jakim prawo do ochrony zdrowia jest prawem podstawowym, z art. 68 ust. 1 Konstytucji może wynikać prawo podmiotowe. Dotyczy to wspomnianych wyżej związków ochrony zdrowia z godnością człowieka i innymi prawami podstawowymi"; idem, Konstytucyjne prawo do ochrony zdrowia jako prawo socjalne i prawo podstawowe, „Roczniki Administracji i Prawa” 2012, nr 12, s. 97.

58 Zob. wyroki z dnia: 23 marca 1999 roku, sygn. K 2/98, OTK ZU nr 3/1999, poz. 38; 7 stycznia 2004 roku, sygn. K 14/03, OTK ZU nr 1/A/2004, poz. 1; 29 września 2015 roku, sygn. K 14/14, OTK ZU nr 8/A/2015, poz. 124.

59 Zob. P. Zamelski, op. cit., s. 69

${ }^{60}$ Ibidem, s. 70

61 B. Kmieciak, Prawa dziecka jako pacjenta, Warszawa 2016, s. 282. 
cjalnych, które wiąże się z prawem do otrzymania pomocy oraz zagwarantowania należnych dziecku świadczeń. Prawo to znalazło swoje wyraźne potwierdzenie w normach Konstytucji, przede wszystkim w art. 71 ust. 1, który stanowi, że „Państwo w swojej polityce społecznej i gospodarczej uwzględnia dobro rodziny. Rodziny znajdujące się w trudnej sytuacji materialnej i społecznej, zwłaszcza wielodzietne i niepełne, mają prawo do szczególnej pomocy ze strony władz publicznych”. Przepisy Konstytucji nakładają na państwo obowiązek udzielania pomocy rodzinom znajdującym się $\mathrm{w}$ trudnej sytuacji materialnej, zwłaszcza rodzinom wielodzietnym i niepełnym. Zasada pomocniczości państwa i innych instytucji publicznych względem rodziny oznacza, że państwo wspiera wysiłki rodziny, nie wyręczając jej w staraniach o zapewnienie godziwego poziomu życia. Nie bez znaczenia dla realizacji praw socjalnych dziecka są regulacje zawarte w art. 27 Konwencji o Prawach Dziecka. Dotyczą one obowiązku uznania przez państwo prawa każdego dziecka do poziomu życia odpowiadającego jego rozwojowi fizycznemu, psychicznemu i społecznemu (art. 27 ust. 1). Obowiązek zapewnienia odpowiednich warunków życia spoczywa, stosownie do ich możliwości, na rodzicach i innych osobach odpowiedzialnych za dziecko (art. 27 ust. 2). W sytuacji gdy rodzice nie są w stanie zapewnić dziecku warunków odpowiednich do życia i rozwoju, zagwarantowanie mu godziwych warunków socjalnych staje się obowiązkiem władz publicznych (art. 27 ust. 3).

Do zakresu działalności Rzecznika Praw Dziecka należy też prawo dziecka do nauki (art. 3 ust. 2 pkt 4). Na marginesie tych rozważań można zauważyć, że prawo do nauki należy do podstawowych praw jednostki we współczesnym społeczeństwie. Istotne dla tej sprawy jest też zaakcentowanie stanowiska TK, zgodnie z którym prawo to powinno być postrzegane „zarówno w kategoriach dobra i wartości indywidualnej, jak i ważnego, podstawowego dobra społecznego"62. Jednocześnie sąd konstytucyjny zwrócił uwagę, że „urzeczywistnienie prawa do nauki jest nie tyle szczególnym przywilejem współczesnego człowieka, ile stanowi nieodzowny warunek rozwoju społeczeństwa i jednocześnie pełnego uczestnictwa jednostki w życiu społecznym”63. Zdaniem TK „powszechne kształcenie stało się najważniejszym motorem rozwoju gospodarczego i cywilizacyjnego we współczesnym świecie" 64 .

Nie bez znaczenia dla określenia statusu prawa do nauki jest regulacja zawarta $\mathrm{w}$ art. 70 Konstytucji RP, która nadała temu prawu nie tylko formalnie rangę konstytucyjną, ale też wprowadziła go do katalogu praw ekonomicznych, socjalnych i kulturalnych ${ }^{65}$. Zgodnie z treścią art. 70 ust. 1 Konstytucji każdy

62 Wyrok TK z dnia 5 czerwca 2014 roku, sygn. K 35/11, OTK-A 2014/6/61.

63 Ibidem.

64 Ibidem.

65 W literaturze przedmiotu prawo do nauki jest ujmowane zazwyczaj jako prawo kulturalne; zob. M. Drejs, Prawo do nauki, [w:] Polska wobec europejskich standardów praw człowieka. Materiaty konferencji naukowej doktorantów i studentów UMK ,W pięćdziesięciolecie Europejskiej 
ma prawo do nauki. Jednocześnie przepis ten stanowi, że nauka do 18 roku życia jest obowiązkowa. Natomiast sposób wykonywania obowiązku szkolnego określa ustawa. Trzeba też dodać, że wśród elementów składających się na gwarantowane konstytucyjnie prawo do nauki jest zasada bezpłatności nauczania w szkołach publicznych (art. 70 ust. 2) oraz powszechny i równy dostęp do wykształcenia jako konieczny element prawa do nauki (art. 70 ust. 4 Konstytucji). Jako pozostałe elementy należy wskazać przede wszystkim autonomię szkół wyższych (art. 70 ust. 5) oraz prawo obywateli i instytucji do tworzenia niepublicznych zakładów oświatowych wszystkich szczebli do szkół wyższych włącznie (art. 70 ust. 3).

Jest przy tym sprawą oczywistą i naturalną, że prawo dziecka do nauki łączy się z obowiązkiem nauki (jest w rzeczywistości konstytucyjnym obowiązkiem kształcenia) ${ }^{66}$ nałożonym na wszystkie niepełnoletnie osoby, wykonywanym pod nadzorem rodziców oraz odpowiednich władz publicznych ${ }^{67}$. Z tego punktu widzenia charakterystyczna jest rola rodziców (opiekunów prawnych), którzy ponoszą główną odpowiedzialność za wychowanie i ukierunkowanie kształcenia dzieci zgodnie z własnymi przekonaniami (art. 48 w związku z art. 53 ust. 3) ${ }^{68}$. Ponadto przepis art. 70 ust. 3 Konstytucji przyznaje rodzicom wolność w wyborze dla swych dzieci szkół innych niż publiczne.

Wypada też zaznaczyć, że o uznaniu prawa dziecka do nauki oraz o realizowaniu tego prawa na zasadzie równych szans, jak też o nauczaniu podstawowym jako obowiązkowym i bezpłatnym dla wszystkich stanowi art. 28 ust. 1 pkt a) Konwencji o Prawach Dziecka. Jednocześnie w świetle art. 29 ust. 1 pkt a) Konwencji nauka dziecka powinna być ukierunkowana na rozwijanie w jak najpełniejszym zakresie osobowości, talentów oraz zdolności umysłowych i fizycznych dziecka. Prawo do nauki, w tym „możliwość korzystania z bezpłatnej nauki obowiązkowej”, gwarantuje też art. 14 ust. 2 Karty praw podstawowych $\mathrm{UE}^{69}$. Ponadto w ust. 3 cytowanego artykułu zagwarantowano swobodę wyboru placówki edukacyjnej oraz prawo rodziców do zagwarantowania wychowania i nauczania ich dzieci zgodnie z własnymi przekonaniami religijnymi, filozoficznymi i pedagogicznymi. Także zgodnie z art. 17 ust. 2 zrewidowanej EKS ${ }^{70}$ państwa zobowiązują się do podjęcia ,wszelkich koniecznych i odpowiednich środków zmierzających do

Konwencji Praw Człowieka i dziesięciolecie Katedry Praw Człowieka i Prawa Europejskiego UMK”, red. T. Jasudowicz, Toruń 2001, s. 89.

66 Przyznając prawo do nauki, ustrojodawca uczynił edukację jednocześnie obowiązkową do ukończenia 18 roku życia; zob. R. Raszewska-Skałecka, Szkoła publiczna jako zdecentralizowany podmiot administracji publicznej. Studium administracyjnoprawne, Wrocław 2019, s. 93.

67 Zob. H. Babiuch, Konstytucyjny charakter i zakres ochrony prawa dziecka do nauki, ,Zeszyty Naukowe Państwowej Wyższej Szkoły Zawodowej im. Witelona w Legnicy” 2008, nr 4, s. 12.

68 Ibidem, s. 13.

69 Dz.Urz. UE 2016/C 202/02.

70 Ze względu na konieczność uzupełnienia i rozwinięcia praw ujętych w treści Europejskiej Karty Społecznej opracowano tekst (zrewidowanej) EKS, zawierający rozszerzony katalog praw społecznych. Akt ten został podpisany 3 maja 1996, a wszedł w życie 1 lipca 1999 roku. 
[...] zapewnienia dzieciom i młodocianym bezpłatnego kształcenia na szczeblu podstawowym i średnim, a także podejmowania środków promujących regularne uczęszczanie do szkoły"71.

Należy także zauważyć, że wśród priorytetów Rzecznika Praw Dziecka wymienia się działania zmierzające do ochrony dziecka przed przemocą, okrucieństwem, wyzyskiem, demoralizacją, zaniedbaniem oraz innym złym traktowaniem (art. 3 ust. 3 ustawy o Rzeczniku Praw Dziecka).

W tym miejscu warto zaznaczyć, że zjawisko przemocy ma złożony charakter. $\mathrm{Z}$ tego względu na gruncie badań różnych dyscyplin naukowych — psychologii, pedagogiki, prawa, socjologii, filozofii i medycyny — zwraca się uwagę na różnorodne aspekty tego zagadnienia, a mianowicie: formy przemocy, czynniki zwiększające ryzyko wystąpienia przemocy wobec dzieci oraz formy i możliwości terapii czy profilaktyki, jak również rozwiązania prawnokarne problemu ${ }^{72}$. We współczesnej literaturze pojęcie przemocy jest niekiedy stosowane zamiennie z takimi określeniami jak: „maltretowanie”, „nadużycie”, „krzywdzenie”, „złe traktowanie" 73 .

W literaturze przemoc wiązana jest najczęściej z działaniem intencjonalnym, mówimy o niej w sytuacji, gdy szkoda nie powstała w sposób przypadkowy ${ }^{74}$. Wskazuje się też, że przemoc mająca za cel krzywdzenie dzieci może przybierać różnorakie formy, „które są lub mogą być niszczące dla psychofizycznego rozwoju małoletniego"75. Przemoc może mieć zarówno formę fizyczną (gdy dziecko dozna faktycznego uszkodzenia ciała bądź gdy istnieje duże ryzyko, że dane działanie mogłoby je spowodować) ${ }^{76}$ oraz psychiczną (emocjonalną) polegającą na świadomym niszczeniu lub znaczącym obniżaniu możliwości rozwojowych dziecka poprzez na przykład ośmieszanie, wystosowywanie gróźb, wyszydzanie, nadmierny rygor, zastraszanie, znęcanie się $\mathrm{w}$ formie słownej ${ }^{77}$.

Warto też zwrócić uwagę na definicję przemocy fizycznej wobec dziecka przyjętą przez Światową Organizację Zdrowia, w świetle której oznacza ona taką

71 Agencja Praw Podstawowych Unii Europejskiej i Rada Europy, Podręcznik prawa europejskiego dotyczacego praw dziecka, https://www.echr.coe.int/Documents/Handbook_rights child_POL.PDF (dostęp: 9.02.2021).

$\overline{7} 2$ Szerzej zob. E. Jarosz, Zjawisko przemocy wobec dzieci jako problem społeczny, „Chowanna" 2, 1995, s. 16.

73 Ibidem.

74 S. Wójcik, Przemoc fizyczna wobec dzieci, „Dziecko Krzywdzone. Teoria, badania, praktyka" 2012, nr 2, s. 8 .

75 J. Helios, W. Jedlecka, Wspótczesne oblicza przemocy. Zagadnienia wybrane, Wrocław 2017, s. 77.

76 S. Wójcik, op. cit., s. 8.

77 Por. S.L. Stadniczenko, Ochrona dziecka przed przemoca, okrucieństwem, wyzyskiem, demoralizacja, zaniedbywaniem oraz innym złym traktowaniem, [w:] Prawa dziecka po przystapieniu do Unii Europejskiej. Materiaty z konferencji Rzecznika Praw Dziecka, red. M. Potapowicz, M. Krauzowicz, P. Przybylski, Warszawa 2004, s. 72. 
przemoc „w wyniku której dziecko doznaje faktycznej fizycznej krzywdy lub jest nią potencjalnie zagrożone. Krzywda ta następuje w wyniku działania bądź zaniechania działania ze strony rodzica lub innej osoby odpowiedzialnej za dziecko, lub której dziecko ufa bądź która ma nad nim władzę. Przemoc fizyczna wobec dziecka może być czynnością powtarzalną lub jednorazową".

Niewątpliwie ochrona dziecka przed przemocą, okrucieństwem, wyzyskiem i demoralizacją jest wartością konstytucyjną. Zgodnie z art. 72 ust. 1 Konstytucji RP „Rzeczpospolita Polska zapewnia ochronę praw dziecka i każdy ma prawo żądać od organów władzy publicznej ochrony dziecka przed przemocą, okrucieństwem, wyzyskiem i demoralizacją”. Można zgodzić się z tezą, że treść tego przepisu zakłada „ogólne uznanie dobra dziecka za samoistną wartość konstytucyjną, uzupełniającą wartość szerszą jaką jest dobro rodziny”. Z kolei „obowiązkiem ustawodawcy zwykłego jest stworzenie szczegółowych unormowań pozwalających na urzeczywistnienie dobra dziecka, a proces wykładni i stosowania wszelkich przepisów prawa musi uwzględniać obowiązek realizacji tej wartości konstytucyjnej"78. Szczególna waga i znaczenie art. 72 ust. 1 Konstytucji wynika stąd, że przepis ten pozostaje w bezpośrednim związku także z art. 30 Konstytucji, który uznaje przyrodzoną i niezbywalną godność człowieka, a więc bez wątpienia także dziecka ${ }^{79}$.

Aby rzucić nieco światła na współczesne dociekania na temat godności człowieka, należy koniecznie zwrócić uwagę na fakt, że stanowi ona wzorcową zasadę, podstawę, w oparciu o którą można by ustanawiać reguły, zasady i standardy prawa. Dla interpretacji tego, co należy rozumieć jako godność człowieka, zasadniczego znaczenia nabiera art. 30 Konstytucji RP, zgodnie z którym ,„przyrodzona i niezbywalna godność człowieka stanowi źródło wolności i praw człowieka i obywatela. Jest ona nienaruszalna, a jej poszanowanie i ochrona jest obowiązkiem władz publicznych”. Pojęcie ,,przyrodzonej” godności człowieka oznacza, że godność człowieka jest czymś swoiście własnym, należnym każdemu człowiekowi, bo danym mu wraz z byciem sobą. Ustawa zasadnicza stwierdza słusznie, że godność jest niezbywalna, co nie tylko znaczy, że nie można jej nikomu odstąpić, ale że jest ona ściśle związana z człowieczeństwem. Godność człowieka jest dana jako rzeczywistość niezbywalna, domagająca się przyjęcia i uznania. Nienaruszalność godności oznacza, że nie można odebrać człowiekowi prawa do szacunku. Pojęcie „poszanowania” godności oznacza obiektywne prawo do szacunku oraz subiek-

78 Zob. wyrok TK z dnia 29 czerwca 2016 roku, SK 24/15, OTK-A 2016/46. Por. L. Garlicki, Uwagi do art. 72, [w:] Konstytucja Rzeczypospolitej Polskiej. Komentarz, t. 3, red. L. Garlicki, Warszawa 2003, s. 2-3.

79 B. Banaszak, Ł. Żukowski, Prawo dziecka do ochrony przed przemoca, okrucieństwem, wyzyskiem i demoralizacja — rozwiąania polskie na tle standardów Konwencji o Prawach Dziecka, [w:] Konwencja o Prawach Dziecka..., s. 239. 
tywne respektowanie tego prawa do szacunku ${ }^{80}$. $Z$ tego, że prawo do szacunku jest nienaruszalne, wynika, że władze publiczne są zobowiązane do poszanowania tego prawa, a tam, gdzie byłoby ono zagrożone lub lekceważone — do jego ochrony ${ }^{81}$.

Nie bez znaczenia w kwestii godności ludzkiej jest stanowisko Trybunału Konstytucyjnego, który przypisał temu pojęciu „charakter wartości konstytucyjnej o centralnym znaczeniu dla zbudowania aksjologii obecnych rozwiązań konstytucyjnych, przez pryzmat której należy dokonywać wykładni i stosowania wszystkich pozostałych postanowień o prawach, wolnościach i obowiązkach jednostki" ${ }^{\prime 2}$. Istotne dla tej sprawy jest też zaakcentowanie znaczenia funkcji, jakie pełni „godność człowieka” w porządku konstytucyjnym. Trybunał Konstytucyjny podkreślił przy tej okazji, że „godność człowieka nie może być traktowana jako przeżytek okresu feudalnego". Zdaniem Trybunału pełni ona w porządku konstytucyjnym kilka funkcji:

— łącznika między Konstytucją (akt prawa pozytywnego) a porządkiem prawnonaturalnym,

- determinanty interpretacji i stosowania Konstytucji,

— wyznacznika systemu i zakresu poszczególnych praw i wolności,

— podmiotowego prawa jednostki o odrębnej treści prawnej,

— zasady konstytucyjnej o charakterze normatywnym,

— aksjologicznej podstawy i przesłanki całego porządku konstytucyjnego ${ }^{83}$.

Trybunał wyraźnie opowiedział się za uprzedniością godności każdego człowieka w stosunku do państwa, a przez to potwierdził jej przyrodzony charakter. Przyjął przy tym wysoki standard ochrony ludzkiej godności, obejmując nią również dzieci w fazie prenatalnej. Wart odnotowania jest tu fakt, że sąd konstytucyjny nie różnicuje, nie stopniuje nienaruszalnej godności i nie ulega pokusie wartościowania życia ludzkiego, kierując się względami pragmatycznymi ${ }^{84}$.

Bez wątpienia wolność od przemocy, okrucieństwa, wyzysku i demoralizacji, której podmiotem uprawnionym stosownie do treści art. 72 ust. 1 zd. 2 Konstytucji RP jest każde dziecko, wydaje się być wolnością nawiązującą wprost do istoty godności ludzkiej i wyrażającą jej kwintesencję. Jako taka ma podstawowe znaczenie dla ochrony i poszanowania godności dziecka ${ }^{85}$. Ponadto ochrona dziecka przed

80 Por. R. Czekalski, Personalistyczna pedagogika wychowawcza Jana Pawła II, „Warszawskie Studia Teologiczne" 21, 2008, s. 186.

81 Zob. J. Blicharz, Administracja publiczna i spoleczeństwo obywatelskie w państwie prawa, Wrocław 2012, s. 28-29. Także w tej sprawie: J. Blicharz, Niepomijalność podmiotowości człowieka i niepomijalność misji administracji publicznej w służbie dobru wspólnemu (dobru osobowemu), „Prawo" 331, 2020, s. 21-24.

82 Wyrok TK z 30 września 2008 roku, sygn. K 44/07, OTK ZU nr 7/A/2008, poz. 126.

83 Zob. P. Polak, J. Trzciński, Konstytucyjna zasada godności człowieka w świetle orzecznictwa Trybunału Konstytucyjnego, „Gdańskie Studia Prawnicze” 40, 2018, s. 266.

${ }^{84}$ Ibidem.

85 E.H. Morawska, Ochrona praw dziecka w świetle art. 72 Konstytucji RP. Uwagi na tle orzecznictwa Trybunału Konstytucyjnego, „Kwartalnik Prawa Publicznego” 2007, nr 4, s. 140. 
wszelkimi formami przemocy fizycznej i psychicznej, w tym wykorzystywania dla celów seksualnych, znalazła też swoje wyraźne potwierdzenie w art. 19 KPD.

\section{KONKLUZJE}

Reasumując, należy stwierdzić, że regulacje Konstytucji nadały ochronie praw dziecka nie tylko formalnie rangę konstytucyjną, ale także wprowadziły obowiązki organów władzy publicznej do przestrzegania tych norm konstytucyjnych, jak również norm prawa międzynarodowego odnoszących się do ochrony praw dziecka i rodziny. Można więc uznać, że współcześnie ochrona praw dziecka wywiera konkretny i widoczny wpływ na funkcjonowanie całości systemu prawa, którego głównym założeniem jest nakaz uwzględniania „dobra dziecka” w procesie stanowienia i stosowania prawa. Nie może jednak budzić wątpliwości, że wyodrębnienie sfery praw dziecka i przyznanie im ochrony konstytucyjnej kieruje uwagę na te aspekty godności dziecka, które dzisiaj są być może szczególnie mocno zagrożone w wyniku rozwoju cywilizacyjnego, a także występujących procesów globalizacji.

\section{PROTECTION OF RIGHTS OF THE CHILD IN LIGHT OF POLISH CONSTITUTION OF 1997 - NORMATIVE FRAMES}

\section{Summary}

Protection of rights of the child has gained a very strong legal foundation, constituted by international as well as national law. The provisions of Constitution granted the formal legal basis to the protection of rights of the child, and they also introduced the legal duties of public authorities to respects these provisions, as well as to observe the norms of international law which are concerned with the protection of the child and family. It is correct to say that contemporarily the protection of rights of the child specifically and visibly affects the functioning of the whole legal system the main assumption of which is the obligation to take into account "the good of the child" in the process of creation and application of law.

Keywords: human rights, welfare of a child, protection of rights, protection of human rights

\section{BIBLIOGRAFIA}

Babiuch H., Konstytucyjne prawa rodziców w zakresie wychowania dziecka, https://repozytorium. uni.wroc.pl/Content/52921/PDF/10_Helena_Babiuch.pdf.

Babiuch H., Konstytucyjny charakter i zakres ochrony prawa dziecka do nauki, „Zeszyty Naukowe Państwowej Wyższej Szkoły Zawodowej im. Witelona w Legnicy” 2008, nr 4.

Banaszak B., Jabłoński M., Uwagi do artykułu 72, [w:] Konstytucje Rzeczypospolitej oraz komentarz do Konstytucji RP z 1997 roku, red. J. Boć, Wrocław 1999. 
Banaszak B., Konstytucja Rzeczypospolitej Polskiej. Komentarz, Warszawa 2009.

Banaszak B., Żukowski Ł., Prawo dziecka do ochrony przed przemoca, okrucieństwem, wyzyskiem i demoralizacja — rozwiazania polskie na tle standardów Konwencji o Prawach Dziecka, [w:] Konwencja o Prawach Dziecka. Wybór zagadnień (artykuty i komentarze), red. S.L. Stadniczenko, Warszawa 2015.

Bielecki M., Ochrona rodziny i życia rodzinnego w kontekście wychowywania zgodnie z przekonaniami rodziców, Warszawa 2020.

Blicharz J., Administracja publiczna i społeczeństwo obywatelskie w państwie prawa, Wrocław 2012.

Blicharz J., Niepomijalność podmiotowości człowieka i niepomijalność misji administracji publicznej w stużbie dobru wspólnemu (dobru osobowemu), „Prawo” 331, 2020.

Czekalski R., Personalistyczna pedagogika wychowawcza Jana Pawła II, „Warszawskie Studia Teologiczne" 21, 2008.

Dercz M., Konstytucyjne prawo dziecka do szczególnej opieki zdrowotnej, Warszawa 2016.

Dobrowolski M., Status prawny rodziny w świetle nowej Konstytucji Rzeczypospolitej Polskiej, „Przegląd Sejmowy” 1999, nr 4.

Drejs M., Prawo do nauki, [w:] Polska wobec europejskich standardów praw czlowieka. Materiaty konferencji naukowej doktorantów i studentów UMK „W pięćdziesięciolecie Europejskiej Konwencji Praw Człowieka i dziesięciolecie Katedry Praw Człowieka i Prawa Europejskiego UMK”, red. T. Jasudowicz, Toruń 2001.

Garlicki L., Komentarz do art. 2 Europejskiej Konwencji o Ochronie Praw Człowieka i Podstawowych Wolności (dalej: Komentarz EKPC), [w:] Konwencja o Ochronie Praw Człowieka i Podstawowych Wolności, t. 1. Komentarz do artykułów 1-18, red. L. Garlicki, Warszawa 2010.

Garlicki L., Uwaga 3 do art. 18, [w:] Konstytucja Rzeczypospolitej Polskiej. Komentarz, t.3, red. L. Garlicki, Warszawa 2003.

Garlicki L., Uwaga 4 do art. 71, [w:] Konstytucja Rzeczypospolitej Polskiej. Komentarz, t. 3, red. L. Garlicki, Warszawa 2003.

Garlicki L., Uwagi do art. 72, [w:] Konstytucja Rzeczypospolitej Polskiej. Komentarz, t. 3, red. L. Garlicki, Warszawa 2003.

Jabłoński M., Jarosz-Żukowska S., Prawa człowieka i systemy ich ochrony. Zarys wykładu, Wrocław 2010.

Kmieciak B., Prawa dziecka jako pacjenta, Warszawa 2016.

Konstytucje Rzeczypospolitej oraz komentarz do konstytucji RP z 1997 roku, red. J. Boć, Wrocław 1998.

Krzesińska-Żach B., Pedagogika rodziny. Przewodnik do ćwiczeń, Białystok 2007.

Makietlo-Jarża G., Rodzina, [hasło w:] Encyklopedia psychologii, red. W. Szewczuk, Warszawa 1998.

Mendecka K., Klauzula dobra dziecka w Konwencji o Prawach Dziecka i w prawie polskim (wybrane problemy), „Acta Universitatis Lodziensis Folia Iuridica” 2016, nr 77.

Mikołajczyk-Lerman G., Konwencja o Prawach Dziecka a realizacja praw dziecka z niepetnosprawnościa w relacjach rówieśniczych, „Przegląd Socjologii Jakościowej” 13, 2017, nr 4.

Mikos M., Urbaniak M., Prawo do bezpiecznej ochrony zdrowia w świetle Konstytucji RP oraz rekomendacji Rady Europy i Rady Unii Europejskiej, „Medyczna Wokanda” 2016, nr 8.

Morawska E.H., Ochrona praw dziecka w świetle art. 72 Konstytucji RP. Uwagi na tle orzecznictwa Trybunału Konstytucyjnego, „Kwartalnik Prawa Publicznego” 2007, nr 4.

Partyk A., Dobro dziecka jako wartość nadrzędna przy orzekaniu o władzy rodzicielskiej. Linie orzecznicze, Warszawa 2020.

Piechota M., Konstytucyjne prawo do ochrony zdrowia jako prawo socjalne i prawo podstawowe, „Roczniki Administracji i Prawa” 2012, nr 12.

Polak P., Trzciński J., Konstytucyjna zasada godności człowieka wświetle orzecznictwa Trybunału Konstytucyjnego, „Gdańskie Studia Prawnicze” 40, 2018.

Przegląd Prawa i Administracji 127, 2021

(C) for this edition by CNS 
Radwański Z., Pojęcie i funkcja „dobra dziecka” w polskim prawie rodzinnym i opiekuńczym, „Studia Cywilistyczne” 31, 1981.

Raszewska-Skałecka R., Szkoła publiczna jako zdecentralizowany podmiot administracji publicznej. Studium administracyjnoprawne, Wrocław 2019.

Stadniczenko S.L., Ochrona praw dziecka wynikajaca z art. 19 Konwencji o Prawach Dziecka oraz art. 72 Konstytucji RP, „Zeszyty Naukowe Państwowej Wyższej Szkoły Zawodowej im. Witelona w Legnicy" 2017, nr 22.

Stadniczenko S.L., Prawa dziecka częścia składowa systemu praw człowieka i obywatela, [w:] Konwencja o Prawach Dziecka. Wybór zagadnień (artykuty i komentarze), red. S.L. Stadniczenko, Warszawa 2015.

Stadniczenko S.L., Prawo dziecka do wychowania w rodzinie, [w:] Konwencja o Prawach Dziecka. Wybór zagadnień (artykuty i komentarze), red. S.L. Stadniczenko, Warszawa 2015.

Stadniczenko S. L., Ochrona dziecka przed przemoca, okrucieństwem, wyzyskiem, demoralizacja, zaniedbywaniem oraz innym złym traktowaniem, [w:] Prawa dziecka po przystapieniu do Unii Europejskiej. Materialy z konferencji Rzecznika Praw Dziecka, red. M. Potapowicz, M. Krauzowicz, P. Przybylski, Warszawa 2004.

Stojanowska W., Władza rodzicielska pozamalżeńskiego i rozwiedzionego ojca. Studium socjologiczno-prawne, Warszawa 2000.

Sylwestrzak A., O klauzuli generalnej dobra rodziny, „Studia Prawnoustrojowe” 2019, nr 45.

Zacharko L., Wartenberg-Kempka B., Dobro dziecka jako wartość najwyższa w prawie administracyjnym, [w:] Aksjologia prawa administracyjnego, t. 1, red. J. Zimmermann, Warszawa 2017.

System prawa rodzinnego i opiekuńczego, red. J.S. Piątowski, Warszawa 1985.

Zamelski P., Prawo do życia i ochrony zdrowia, [w:] Konwencja o Prawach Dziecka. Wybór zagadnień (artykuly i komentarze), red. S.L. Stadniczenko, Warszawa 2015.

Zdyb M., Ochrona praw dzieci w prawie polskim i międzynarodowym w kontekście ochrony ich zdrowia, „Studia Prawnicze KUL” 2018, nr 4.

Zdyb M., Systemowe obowiazki państwa w zakresie poszukiwania optymalnego modelu odpowiedzialności zwiąanej z ochrona zdrowia. Zagadnienia podstawowe, [w:] Odpowiedzialność w ochronie zdrowia, red. M. Zdyb, E. Kruk, A. Wołoszyn-Cichocka, Warszawa 2018.

Ziółkowska A., Gronkiewicz A., Rodzina w prawie administracyjnym — prolegomena, [w:] Rodzina w prawie administracyjnym, red. A. Ziółkowska, A. Gronkiewicz, Katowice 2015.

Zoll A., Problemy stużby zdrowia w świetle doświadczeń RPO, „Prawo i Medycyna” 2000, nr 8.

Żukowski Ł., Rola Rzecznika Praw Dziecka w ochronie praw dzieci, [w:] Realizacja i ochrona konstytucyjnych wolności i praw jednostki w polskim porzadku prawnym, red. M. Jabłoński, Wrocław 2014. 